\title{
The implications of international rescue and relief operations for domestic regulatory regimes-lessons from the 2011 East Japan Earthquake
}

\author{
Yoshi Kodama(B)
}

\begin{abstract}
This article attempts to reveal how and why international rescue and relief operations had difficulties, following the 2011 East Japan earthquake, in being smoothly received in a country like Japan with well-prepared domestic natural disaster response mechanisms as well as highly regulated economy and society. To this end, the article examines lessons and challenges from the operations by foreign rescue and relief assistance teams then tries to present possible solutions and prescriptions for adjustment and improvement of inter-state frameworks as well as domestic laws and regulations. Issues are generally analogous to trade and investment liberalisation as well as interstate deregulatory endeavours, which may give some insights in addressing post-disaster regulatory and procedural impediments.
\end{abstract}

\section{Introduction}

This article attempts to reveal how and why international rescue and relief operations had difficulties at the 2011 East Japan Earthquake in being smoothly received in a country like Japan with well-prepared domestic natural disaster response mechanisms as well as highly regulated economy and society. To this end, the article examines lessons and challenges regarding the operations of foreign rescue and relief assistance teams, then endeavours to present possible solutions and prescriptions for further adjustment and improvement of intergovernmental frameworks as well as

\footnotetext{
Correspondence: yoshinori.kodama@mofa.go.jp

BL(Tokyo), LLM(Cantab), PhD(London). The views expressed in this article are purely personal to the author. The analyses and views in this article are based upon the author's discussions and enquiries with experts, professionals, and negotiators in 2014-2018. The author particularly extends appreciation to insights and advice from Ms Gabrielle Emery, Coordinator for Asia Pacific Disaster Law Program, International Federation of Red Cross and Red Crescent Societies, Asia Pacific Regional Office; as well as Mr Steven Hill, Legal Adviser and Director, North Atlantic Treaty Organization. Japanese Ministry of Foreign Affairs, Tokyo, Japan
}

domestic laws and regulations. In this juncture, existing intergovernmental instruments, either bilateral or regional, as well as multilateral, will be examined, and further improvement will be prescriptively presented.

The method of analysis in this article is based upon the 'bottom-up' approach. This means to examine each phase and aspect of rescue and relief activities, then to analyse relevant domestic regulations as well as international instruments, so as to seek possible adjustments or amendments for existing frameworks. There may be an alternative approach to tackle challenges by codifying comprehensive multilateral legally binding instruments covering relevant aspects with institutional backings, such as collective decision-making processes and dispute settlement procedures dealing with discrepancies in application (International Law Commission (ILC) 2016, as an example of comprehensive legislative approach). Such an approach will be useful as a mid-term objective, but the author here tries to seek possibilities to utilise 
existing instruments and frameworks to a maximum extent as a practical and low-cost option. ${ }^{1}$

Here is a factual basis for analyses in this article. The east coast of the northeast region of Japan was hit by an unprecedentedly large-scale earthquake on 11 March 2011. Its epicentre was located under the seabed off the coast, causing direct damage as well as a series of tidal waves to coastal communities (Joint Editorial Committee for the Report on the Great East Japan Earthquake Disaster 2014: ch 2, 12). The earthquake brought about a significant number of casualties as well as physical damage to buildings and infrastructures, leading to a total or partial eradication of towns and villages as well as paralysis of lifelines (Japanese Fire and Disaster Management Agency 2013: ch 3). This damage further caused protracted difficulties in the recovery of agricultural and industrial supply sources.

The examination with reflections on the 2011 East Japan Earthquake as well as subsequent international rescue and relief operations will be presented in the following order:

In the first part, lessons of emergency rescue and recovery operations, typically revealed by the 2011 East Japan Earthquake, will be presented, with due considerations to impediments caused by heavily structured sophisticated domestic regulations and standards. This will include in chronological order the entry of rescue teams, including rescue dogs; the use of airport and seaports for receiving rescue teams and emergency materials; movement and transport of teams and materials to affected areas, including the issues of transport permissions, traffic tolls/charges, driving license, and vehicle registrations; customs and quarantines for belongings and emergency materials; and medical treatment by foreign medical professionals.

In the second part, following upon from the lessons and challenges above, special needs and possible prescriptions will be explored. This will lead to the necessity of adjusting domestic rules and regulations, on the one hand, and the improvement of intergovernmental frameworks as disciplines and guidance for receiving states. Emergency rescue operations need swift and timely

\footnotetext{
${ }^{1}$ There may be an approach to explore humanitarian assistance and disaster rescue/relief operations comprehensively. Such an approach will provide useful overviews with common items, such as the entry and departure of assistance teams, as well as transport within the host state. Immunities from local laws and regulations will be a common issue for both rescue team members and humanitarian aid workers to a certain extent, albeit possible differences in terms of urgency in operations. There are, however, some aspects with distinctive urgency in rescue and initial relief operations, such as the entry of rescue dogs and the transport of urgently needed emergency materials. Disaster rescue teams own special features in order to meet the need of emergency medical treatment. Therefore, this article focuses upon emergency operational aspects in disaster rescue and relief operations.
}

initiation and implementation. The first $72 \mathrm{~h}$ is crucial for saving people's lives. In order to save lives which can be saved by prompt and well organised operations, prearranged instruments are a prerequisite, as was acutely recognised in the East Japan Earthquake in 2011.

\section{Challenges of emergency rescue and relief operations in a highly regulated state} Sequential stages of assistance operations

Following the occurrence of a large-scale natural disaster, including an earthquake and subsequent tidal waves, operations typically commence with information collection and immediate evacuation of those affected and those facing risks of further damage. ${ }^{2}$ In the case of an earthquake and tidal waves, aftershocks and repetitive waves further hinder such information collecting activities as well as initial evacuation and rescue operations (International Development Centre of Japan ('Centre') 2014: 2.1). Physical damage may also obstruct the function of central and local administrative authorities, leading to further difficulties in specification of needs as well as coordination for rescue and initial relief operations. In such physically and administratively malfunctioning circumstances, however, investigatory and rescue teams must enter affected areas, then, while reporting to and consulting local operation headquarters, commence search and rescue operations.

This initial stage is followed by, in parallel with continuous rescue operations, relief operations, including the distribution of emergency life-saving materials, such as water, food, and basic sheltering tools. In the course of time, and in the progress of initial rescue and relief operations, the need for emergency materials and services tend to expand and differentiate. Basic life-saving materials at the immediate relief phase are added by more quasi permanent materials, such as tentative housing, daily cleaning, or sanitising tools, as well as portable electricity generators. Evacuees gradually settle down in temporary shelters, recovering their living cycles, with food and clothes, as well as spaces for sleeping.

With the settlement of aftershocks and supplementary damage, operations enter into a new stage of recovery and reconstruction, including the rebuilding of permanent houses as well as basis community infrastructure and facilities, such as roads, bridges, ports, and hospitals, schools, and commercial compounds. Such

\footnotetext{
${ }^{2}$ In this article, 'disaster' mainly means extensive damage and injuries caused by natural events undermining economic and social functions in a broad sense, such as typically earthquake and tsunami, which require physical rescue and relief operations. The current trend of international practice and discussions formulates 'disaster' as covering natural and technological/industrial damage, including cyberattacks and electromagnetic anti-telecommunication pulse explosive devices. See ILC (2016).
} 
reconstruction may include the improvement of resilience against future disasters, by strengthening infrastructure basis and architectural structures (Centre 2014: 2.2).

This is a life-cycle progress following a natural disaster, typically in the case of an earthquake, in particular in relatively remote areas from major centres of a country. There are stages and phases in the progress of assistance operations, corresponding to the need for tackling casualties and damage. One should be careful about categorising and planning too rigidly in terms of time sequence and phases. Assistance operations should counter varying and changing needs on the spot. Operations and activities always overlap with parallel progresses. Even so, standard formulation of phases and steps serve well for planning and resource allocations, by providing perspectives for needs and necessary operations as typical patterns, contributing to predictability and efficiency in preparations.

The different stages of needs and operations also give us insight in justifying emergency deregulatory measures and treatment, in order to eliminate impediments on rescue and relief operations, if necessary and appropriate as a policy choice. The varying intensity of emergency and urgency may affect policy considerations for exemptions from existing regulations and standards which had been created for peacetime daily living conditions, for instance.
From these perspectives, sequential stages and phases in terms of damage and casualties following a large-scale natural disaster can be summarised in Fig. 1, which describes the outline of sequences. (Stages and phases are not exclusively clear-cut, generally overlapping with preceding phases fading off in the course of time. This is described in the table with dotted line arrows indicating elongation of the particular phase.)

Several existing international frameworks or guidelines provide phases and steps for post-disaster assistance operations, generally analogous to the abovementioned staging based upon practical needs and actual operations following the occurrence of a large-scale natural disaster. As mentioned before, one should avoid rigid categorisation of phases, due to the duplication of needs and operational requirements, as seen in the parallel operations of deploying search and rescue teams as well as distributing initial relief emergency materials, such as water and food.

The 2012 OCHA International Search and Rescue Advisory Group Guidelines, as an intergovernmental basis for guidance and reference, mainly focus upon initial rescue operations (Office for the Coordination of $\mathrm{Hu}$ manitarian Affairs (OCHA) 2012. As recent publications regarding humanitarian logistics, United Nations General Assembly (UNGA) 2015; United Nations Office for Disaster Risk Reduction 2015; United Nations Economic and Social Council (ECOSOC) Integration Segment




2014; International Alert 2015; Mitchell 2012). The OCHA Guidelines may well extend more extensively to further subsequent phases with differentiated qualitative aspects in different phases, which will provide basis for examining policy responses to different phases, based upon varying needs for emergency deregulatory measures and treatment. The details will be examined later in this article.

The 2007 International Red Cross Guideline for the Domestic Facilitation and Regulation of International Disaster Relief and Initial Recovery Assistance, as a Red Cross reference instrument for governmental and nongovernmental operations, prescribes the phases of relief and initial recovery (International Federation of Red Cross and Red Crescent (IFRC) 2007a: part I, 4.). 'Relief' means immediate operations, while 'initial recovery' means the restoration and improvement of living conditions (IFRC 2007a: 2). It can be suggested that the Guideline more clearly specify the need for search and rescue operations at the immediate initial stage, clarifying acute policy need for deregulatory and facilitative measures for such operations.

\section{Self-sufficiency and autonomous engagement}

Foreign assistance, not limited to natural disaster emergency assistance, is based upon the rule that the assisting state's offer should be engaged on the basis of acceptance by the recipient state (UNGA 1991: Annex, I, 3; IFRC 2007a: I,4; Sivakumaran 2015). It is also well established that the recipient state has the primary responsibility for tackling natural disaster damage within its territory, thus the assisting state is allowed to engage in assisting operations based upon consent by the recipient state (IFRC 2007a: part I, 3). Such principles derive from the sovereignty of the disaster-affected state, as well as the territoriality principle under established international law (Jennings and Watts 1992: vol I, part 2, ch 5, for instance.). It is also linked with the principles of the nonintervention of domestic matters, as well as the respect of independence and autonomy of the affected state (Jennings and Watts 1992: part 1, ch 1).

At the same time, it frequently happens that, immediately after the occurrence of a large-scale natural disaster, foreign countries quickly make it ready to send search and rescue teams, including medical personnel, as well as emergency assistance materials which are stored in advance in their storehouses. Such readiness and subsequent offers can derive from the need to rescue expatriates and travelers from the assisting state, especially in the case that the affected state is in the neighborhood or vicinity of the assisting state. It may be part of diplomatic policy based upon humanitarian motivation to save human lives and safety. Non-governmental organisations from foreign countries are particularly quick to arrive at an international airport in the affected state, commencing operations in corporation with local philanthropic organisations. Governmental search and rescue teams are also quick to depart their own country without waiting for consent or request from the affected state, waiting for such procedures to be fulfilled at an international airport in the affected state. Pressure upon the central government of the affected state inevitably increases for admitting and coordinating such foreign rescue teams and aid materials.

This creates difficulties and hardship particularly to local administrative authorities, as well as domestic search and rescue teams, including local police and fire agencies, which are in the process of reconstructing their organisational structures and gathering necessary resources for their operations. This situation will run into further complications when rescue teams originate, first, from local fire agencies, then from other regions in the recipient state, finally added from third countries, causing the need to coordinate trilateral fronts. Coordination with foreign forces stationed in the affected state will be another factor which requires intergovernmental communications and arrangements.

These situations, particularly at the initial stage, require foreign assistance operations to be self-sufficient in terms of activities and resources including costs, as well as autonomous engagement without relying upon local agencies and resources (UNGA 2016: para 5).

The extent of need for self-sufficiency and selfsustainability required for foreign operations vary, according to the condition of actual natural disasters and local authorities. Relevant elements may be summarised as follows: first, the size and magnitude of damage caused by a natural disaster leading to the lack of resources and physical infrastructures; second, the residual function of local administrative authorities, which may provide coordinating and advising services for foreign teams; then third, different phases of assistance needs, for instance the initial rescue phase may require high level of self-sufficiency to foreign aid teams, compared to later relief phases where transport infrastructures are generally in the process of recovery.

\section{Coordination with domestic rescue and relief operations}

In the planning and implementation of assistance operations, the affected state assumes the primary responsibility based upon the sovereignty principle as well as nonintervention for policy determination and enforcement under domestic laws and regulations (ILC 2016). In the case of a large-scale natural disaster, however, the affected state needs foreign assistance and resources, particularly at initial rescue and relief stages. This is particularly the case when local administrative authorities are severely damaged at initial stages, and even the 
central government is having difficulties in collecting information and implementing effective measures in cooperation with regional local authorities. A paradoxical situation emerges: Foreign assistance in terms of personal and material resources is keenly required, while local authorities lack sufficient administrative capability for receiving foreign assistance as well as coordinating with domestic rescue and relief operations. This may cause a burden upon local authorities as well as local rescue and relief teams by additional administrative and operational work (ILC 2016: 3.2.(3)).

Difficulties in coordination appear in the allocation of operations and, to lesser extent, costs. Personnel and material costs for assistance operations by foreign teams are rationally borne by the assisting state, as a premise of assistance policy avoiding extra burdens upon the affected state. However, the issue remains as to who and how materials and services should be arranged and prepared for rescue and relief operations engaged by foreign teams (IFRC 2007a: part I, 4). Ideally, rescue and relief activities conducted by foreign teams may be supported and facilitated by local authorities, but in the case of a large-scale disaster especially in the initial phase, such rooms are physically and financially limited.

Operational coordination may emerge, mainly in dimensions of, first, entry to the affected country, then access to the affected areas, and, second, on-site rescue and relief activities. In ideal situations, the affected state may set up an entry contact centre at an international port or airports, as was the case in the 2004 Sumatra earthquake, for which the Indonesian government established an entry point centre for concentrating and facilitating entry procedures for foreign assistance teams (IFRC 2013: ch vi, art 25). In implementing on-site operations, an on-site support centre may be established in or around the affected areas, as suggested by the 2012 OCHA Guidelines (OCHA 2012: C.6). This is quite difficult when local administrative authorities are severely damaged, and domestic rescue and relief operations have just begun functioning with limited information and resources. It may be ideally useful to establish a joint operational framework and physical centre, in order to facilitate information sharing and operational coordination. However, with severely damaged infrastructure, on-site operational meetings by rescue and relief teams involving foreign teams will be the maximum they can do for avoiding duplications and redundancy in operations.

Actual cases are positioned in the spectrum between two extremes: the local government's streamlined control, on the one hand, and the lack of effective local governance, on the other. One some occasions, the affected state may have some extent of familiarities in receiving foreign development assistance, with established systems and procedures. This was the case in the 2004 Sumatra earthquake, where the local government facilitated receiving procedures for foreign rescue and relief teams by establishing an entry centre, then applying special facilitative treatment for foreign teams under its domestic laws and regulations (IFRC 2013: ch vi).

The issue of coordination for work and costs may arise in the dimension of various responsibilities assumed by aid workers and operations. In the course of rescue and relief operations, aid workers may cause damage or injury to third parties and their property by negligence. How liabilities caused by such damage or injury be settled and allocated is an issue, requiring ideally predisaster consultation for settlement. The reality is, it is rare for countries, even those prone to natural disasters, to be highly motivated to examine such needs, creating a framework applied to possible assistance operations in future (Centre 2014: Conclusion 1). These are issues more elaborated later in this article, as part of facilitative measures and arrangement for smooth operations engaged by foreign rescue and relief teams.

\section{Regulatory impediments}

When the affected state has well developed in terms of its domestic regulatory and institutional frameworks, where various aspects of human life and activities are heavily regulated by elaborate laws and regulations, rescue and relief operations can be vicariously affected, thus causing unexpected and unintentional impediments to operations. This is similar to the effect of non-tariff measures, consisting of regulatory policy and measures, upon foreign trade and investment to that country, affecting foreign commercial transactions and personnel movement.

As in the case of non-tariff regulatory measures upon trade and investment, regulations are in principle constructed for legitimate purposes, such as public safety, health, and security. The issue is the extent of necessity and proportionality for satisfying such positive purposes, thus it is mainly a matter of quantitative evaluation. How such regulations may reasonably be reduced or flexibly applied depends upon the following aspects, as in the case of the treatment of non-tariff measures in examining its vicarious impeding effects upon foreign trade and investment:

First, risks caused by relaxing the given regulations should be assessed. Regulations are typically established for the purpose of public health, safety, and security. Their relaxation may cause significant consequences in high probabilities, such as the diffusion of epidemic diseases or the destruction of domestic economies. In some cases, such risks may be further intensified in vulnerable hygienic situations after a large-scale natural disaster. Safety regulations upon search and rescue tools, such as 
electric drills and explosive devices, can be reasonably maintained in search and rescue operations for ensuring safety in operations. Regulations are in most cases based upon conditions and circumstances in a particular country. When such conditions and circumstances continuously persist after the natural disaster, and regulatory relaxation could cause further risks, the continuous application of regulatory measures can be reasonably justified.

Second, one should well examine emergency situations which reorder priorities, especially immediately after the occurrence of a natural disaster. The first $72 \mathrm{~h}$ is crucial for saving the lives of those left in collapsed buildings and landslides. Concentration for search and rescue operations is highly required, before any other general recovery and reconstruction operations. When search and rescue teams are urgently required to engage in operations, and primary medical treatment should be conducted with the assistance of medical teams as well as first aid kits and medicine, regulations presupposing normal time conditions may be flexibly applied. When transport infrastructures are severely damaged and traffic controls are dysfunctional, foreign vehicles may be admitted and temporarily allowed to transport rescue teams and emergency materials to and from affected areas. One should consider new priorities and new conditions brought about by disasters, as special emergency situations.

Third, the temporary character of foreign assistance operations can be taken into account in balancing needs for deregulatory measures and flexible treatment. Search and rescue teams stay in affected areas in an intensive manner for around 1 week or 10 days after the occurrence of a disaster in normal cases (Centre 2014: 3.2. (3)). Aid materials are served for temporary needs in a limited length of time. Temporary entry into the affected state and temporary stay in affected areas may be treated distinctively under domestic regulations which presuppose permanency, not temporariness, in treating human activities and commercial transactions.

Fourth, in emergency situations, regulations may be implemented through self-inspection and selfdeclaration by foreign assistance teams and aid workers. This will save burdens on recipient governments. Even in emergency situations, regulatory authorities may reserve their capacities to enforce routine regulatory measures, but in some cases, governmental resources should be reallocated to administrative tasks directly related to rescue, relief, and recovery. In such cases, routine ways to implement regulations cause further burden upon administrative authorities. Flexible applications can be well considered.

These elements may well be taken into account as examples in general examination for the treatment of regulations in the case of natural disaster as emergency situations, with due consideration to comparison between interests and risks. Specific dimensions which require such consideration are summarised as follows:

First, the entry of personnel as members of search and rescue teams should be treated as priority entrants for life-saving, immediately after the occurrence of a natural disaster (OCHA 2012: D.2. 4.2). Members of teams should be subject to facilitative treatment for immigration, customs, and quarantine procedures. Search and rescue dogs may be treated flexibly in quarantine procedures.

Second, access to affected areas for search and rescue teams, including medical personnel, should be facilitated. This consists of the entry of aircraft or vessels to central or local airports or seaports, thus the flexible application of clearance procedures should be considered, including the reduction or exemption of airport and port fees (OCHA 2012: D.3.). Then, one should facilitate transport from such airports or seaports to affected areas, by using remained roads with suitable vehicles and drivers. Traffic regulations and road fees should be flexibly applied. Foreign vehicle registrations and driving licenses should be flexibly treated by balancing public safety requirements. If one requires self-sufficiency and capacity to engage in autonomous activities to foreign rescue teams, foreign vehicles are admitted and foreign driving licenses are validly used, as tools to fulfill self-sufficiency for foreign teams. However, the need to maintain public order in the domain of traffic regulations may persist in such cases, too, thus affecting the extent of flexible treatment for foreign vehicles and driving licenses.

Third, the treatment of assistance materials, either for emergency use or assisting activities, should be flexibly considered (IFRC 2007a: 17). This involves regulation and standards, as will be seen subsequently in this article, for water and food, thus the issue of quarantine from the viewpoint of food safety and hygienic needs, as well as equipment and tools based upon the need for safety (IFRC 2007a: 17.1.a). In examining specific measures, one needs general considerations upon risks and interests, as well as comparison amongst different interests in order to consider reasonably the level of application in an emergency. One may also consider the simplification of procedures for certification and permission, especially at the initial stage of relief operations as urgent requirements.

Fourth, professional qualifications should be considered in a flexible and facilitative manner in emergency situations. This becomes an issue in medical services Convention on International Civil Aviation 2004: Annex 12. Medical doctors qualified under the rules of the assisting state should be allowed to engage in medical activities in the recipient state to which extent, then 
under what conditions and procedures: An issue distinctively arises when the recipient state had established well institutionalised medical qualification systems. Specific cases on the spot can be summarised as follows: First, whether foreign qualified medical doctors are permitted to engage in primary life-saving operations or medicine prescriptions and surgical operations; and second, whether or not foreign doctors are allowed to engage in the treatment of members of their originating country's rescue and aid teams, or beyond this, to local patients, too. Under well-established medical qualification systems in the affected state, there are two methods to cater for this issue: one is to create a list of qualified foreign doctors for emergency situations, and another is to allow for limited scope of medical activities for foreign doctors in accordance with domestic qualification rules.

Finally, deregulatory treatment may be also considered in the case of transit of foreign assistance teams and materials destined to a third state which is affected by a large-scale disaster (IFRC 2007a: 17.2). A typical case is passage and temporary stay around ports and airports by foreign assistance teams. Foreign teams temporarily stay within the territory of a country and in some cases conduct fueling and procurement of aid materials. With the high extent of temporary character, further flexible treatment in terms of customs, immigration, and quarantine should be considered. There is a case of overflight on the territory of a country by an aircraft carrying search and rescue teams and emergency materials, which requires swift and simplified procedures. Overflight involves sovereignty and national security considerations as significant elements for the country in transit. With the clearance of such factors, the process should reasonably be facilitated and ideally simplified.

\section{Standards and specifications}

There are cases where standards and specifications which are designated compulsorily under domestic laws and regulations in the recipient state may affect the smooth implementation of rescue and relief activities. General considerations are the same as the cases for examining regulatory frameworks, as examined in the preceding subsection: Balance should be struck between the need for satisfying public health, safety, and security, on the one hand, and emergency priorities and conditions, on the other. Designated standards presuppose normal time routine conditions and circumstances, thus emergency situations may change the basis for justifying certain standards. The temporary character of assistance operations can also legitimize the flexible application of such standards.

The flexible application of compulsory standards under domestic laws and regulations can become an issue, when such standards are discretionarily formulated and easily changed according to varying situations, not based upon physical necessity like electricity voltages. Specific examples are as follows:

First, quality standards for emergency assistance materials are typical examples (IFRC 2007a: 18.3). Such standards include those for water, food, shelters, electric generator, and temporary houses. Standards at issue may have bearings upon quarantine procedures. Standards are generally discretionarily formulated, presupposing non-emergency conditions; thus, there is room for flexible application, admitting foreign materials to the extent where public safety and health risks are relatively small, due to the temporary character of admission.

Second, standards for transport dimensions can be also considered. As was seen above, tools and equipment used within airports are examples, including the size of pallets and forklifts. This is an issue of harmonising, domestically and internationally, standards suitable for emergency use, and if appropriate equipment is lacking in some areas, it is a matter for the central government of a country to enhance necessary capacity. If a certain country is lacking in resources and financial capacity, donor countries may consider capacity building assistance in bilateral or multilateral cooperation frameworks.

Third, tools for search and rescue operations are also subject to discretionary standards presupposing normal time conditions in highly regulated states. Such tools include vehicles, drills, and chainsaws, which are standardised for safety requirements. This is a case where the application of standards may be exempted for foreign tools in emergency situations as temporary measures. It is also a case in which intergovernmental harmonization may be considered, as common rules amongst countries applied to emergency situations. Balance between the need for public safety and emergency priorities for lifesaving should be struck typically in such cases.

\section{Needs for adjusting domestic laws and regulations for facilitating foreign disaster rescue and relief operations}

This section examines specific aspects of disaster rescue and relief operations by foreign states for an affected state, in terms of domestic regulatory regimes as potential impediments. Existing or prospective intergovernmental frameworks will be explored. For some areas in disaster reliefs, it is not always true that the intergovernmental legally binding instruments may be able to contribute to effective and efficient relief operations. Details of possible deregulatory arrangements may be well handled by model domestic rules to be adjusted to each state's existing laws and regulations for practical operations (IFRC 2013; ILC 2016). Nonetheless, it will be 
considered whether international rule making will be of use for future effective operations in practice.

\section{Rescue dogs}

The role of rescue dogs is vital in the initial rescue phase of large-scale natural disasters. Even a small delay in arrival of rescue dog teams may cause serious human loss. The first $72 \mathrm{~h}$ is crucial for rescuing people, minimising casualties, given the deterioration of buildings and public infrastructure as well as possible aftershocks. Thus, there is need for urgent entry into the affected state and transport within that state for rescue dogs from foreign countries. The initial offers of assistance from neighboring countries normally consist of rescue dogs and medical teams. On other hand, the admission of rescue dogs and the permission of their activities on land concern animal quarantine regulations and procedures, which are areas regulatory authorities are keen to preserve peacetime rules, given the risk of epidemic damage on a wider scale in that country.

In intergovernmental trade and investment frameworks, animal and plant quarantines are treated as selfcontained rules and procedures, based upon the need to protect human health and safety (Agreement on the Application of Sanitary and Phytosanitary Measures 1994). International rules seldom contain the reduction of quarantine regulations, but favors inter-authority coordination to preserve each state's quarantine rules intact (art 12). Whether there is any room that emergency needs may modify or rationalise quarantine rules and procedures, as in the case of customs duties and procedures, will be an issue here.

Quarantine requirements for rescue dogs have threefold dimensions:

First, there is an issue of substantive quarantine rules as themselves. In rabies vaccination, as a typical and widely diffused practice, dogs are required to have completed vaccination injection under domestic laws (World Organisation for Animal Health 2016; Day et al. 2016). Vaccinations are in most cases subject to antibody testing, or serological testing, in order to prove its effectiveness, under, for instance, the World Veterinary Association guidelines, 4 weeks after the injection (Day et al. 2016: E7). After passing this, dogs are required to be subject to revaccination to maintain the first vaccination's effect, which is called 'booster', after 1 year, in standard cases (Day et al. 2016: Puppy Vaccination and the 6 to 12 Month Booster). Then, boosters are repeated in roughly 3 years. (See Fig. 2 on the flow of vaccination process). It will be ideal if all rescue dogs are ready to be transported to the affected state with the completion of antibody testing. However, in an emergency with a grave need for dogs, whether dogs in a training phase may be included in a rescue team becomes an issue. If a certain number of dogs have just finished their first vaccinations, waiting for antibody testing as a proof, would there be no room for using such dogs against risks in urgency? These are practical issues in real natural disaster incidents.

Second, there is an issue of procedural requirements. Dogs which have undergone vaccinations and proof testing are granted veterinary certificates issued by designated professional veterinarians (World Organisation for Animal Health 2016: B, c). What should we do if some dogs are just waiting for the issuance of certificate, after fulfilling all vaccination requirements? Such dogs are not admitted in peacetime. Is there any room for them to contribute to rescue operations?

Third, there is also a dimension of quarantine screening procedures at the entry point, normally at an airport or a seaport (IFRC 2007b: ch11). Dogs are inspected and all necessary documents are checked thoroughly by quarantine officials. In an emergency, a swift process will be required, with the introduction of priority treatment or simplified screening process. What should we do if quarantine offices are damaged by devastating earthquakes, and the number of quarantine officers in full function is significantly reduced as a result of disasters? They cannot commute to airport, due to the devastation of roads and bridges, for instance. This is an issue not limited to rescue dogs, but all trans-frontier procedures which may be affected in the case of natural disasters.

On these issues, the current domestic and international frameworks, legally binding or non-binding, generally contain relatively limited considerations (IFRC 2007a: 9.2.5). There exists significant hesitation for relaxing or modifying substantive quarantine requirements on any occasion, including natural disaster emergencies. There may be an argument that rescue dogs in a training phase, waiting for an antibody proof, could be admitted as far as the assisting state guarantees with necessary documents to be submitted subsequently. In the procedural dimension, veterinary certificates may be collectively and swiftly forwarded by diplomatic or consular channels. It will be of practical use if there is an international framework dealing with these issues, as prearranged rules and procedures or, at least, non-legally binding guidelines.

The treatment of rescue dogs may be based upon epidemic risk assessment approach, so frameworks may be considered with country-based or region-based preexamination as follows: First, past disease records in a state may be analysed, then epidemic conditions of a recipient state may also be examined in terms of epidemic effects possibly caused by, for instance, rescue dogs in a training phase. Second, geographical figures and spaces, either vast open space or closed contained places, may be considered. If natural disaster damage is contained in a remote island, for instance, there may be a room for 


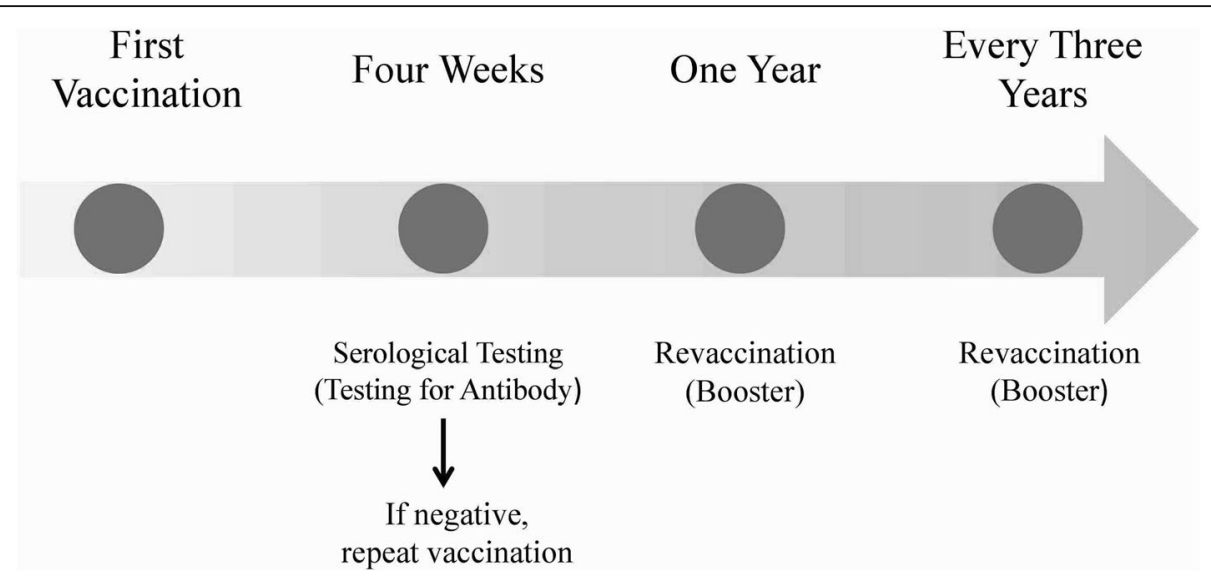

Fig. 2. Canine vaccination timetable (typical cases)

flexible treatment for rescue dog screening procedures. Third, if the recipient state has only primitive facilities and systems for ensuring necessary hygiene levels, the screening procedure should be maintained in a strict manner. Fourth, medical and hygienic conditions of the recipient state can be considered in speculating possible epidemic damage. Fifth, the capacity of a recipient state to treat possible epidemic damage, such as containment and blockage of contagion routes, should be considered. This is an issue of governmental capacity, technically and institutionally, to deal with further emergency situations. All these factors may be possibly considered and analysed in peacetime, not after the occurrence of natural disaster emergency events. Thus, intergovernmental prearrangement for cases will be useful.

Under the current intergovernmental frameworks and instruments, rescue dog issues are only taken into account in a limited manner. The 1970 Istanbul Convention on Temporary Admission stipulates in its Annex D the facilitation of rescue dogs procedures in general but sporadic terms (Convention on Temporary Admission (Istanbul Convention) 1990). The 2003 United National General Assembly Resolution 57/150 calls for the simplification and reduction of animal quarantine proceeds in natural disaster emergency quite generally (UNGA 2003: 3 ). In advanced regional frameworks, for instance, the European Union Regulation 998/2003/EC includes the rules of quarantine procedures for dogs entering from a third country by providing the application of veterinary checks for intra-community movement (European Union (EU) 2003: art 18, etc.). This will create additional procedures in the case of emergency.

It is highly recommendable that rules and guidance for substantive and procedures treatment of rescue dogs in natural disaster emergency be discussed and pursued, taking into account possible real cases in a practical manner, ideally based upon simulation and risk assessment.

\section{Rescue team entry-immigration and port/airport clearance}

At the initial phase of disaster relief operations, rescue teams with well-trained professional rescue workers and medical experts play a key role for life-saving activities. Most countries maintain reserved professional rescue experts mainly for domestic emergency, who can be sent to an affected state immediately after the occurrence of a natural disaster if the affected state seeks or accepts international support (IFRC 2007b: ch10). Then, there arises issues of immigration procedures for foreign rescue team members, as well as entry clearance for the team at an airport or seaport.

Immigration is an exclusive sovereign matter, requiring personnel's identification and the evidence of their eligibilities for entry, such as non-criminal records (Jennings and Watts 1992: 897). Short staying entrants are under strict regulations upon their activities, such as the prohibition of profit-making commercial activities (Jennings and Watts 1992: 897).

In an emergency, there is a strong need for swift entry of rescue workers with simplified screening procedures. Rescue workers enter and stay in the affected state on a temporary basis, with exclusive missions for rescue operations. It will be reasonable that they are promptly admitted, as long as their identity and the scope of activities are guaranteed by administrative channels, like embassy or consular letters. The relaxation of immigration rules and procedures is normally difficult on a nonreciprocal basis, unless there is a prearranged bilateral or multilateral framework for mutual relaxation. Temporary flexible treatment will be also difficult, given its character as a one-off deregulatory measure, since regulations are elaborately constructed as part of intrinsically linked network of rules and practice. Immigration procedures require documentation and proof in ordinary cases. Without past experience or effective trainings, 
immigration officers will face difficulties in simplifying or reducing their screening duties. There may be also cases in which immigration offices are seriously damaged by a natural disaster, causing the lack of human resources. Such dysfunction of administrative capability will create further impediments upon swift entry of rescue teams.

There are generally practices of simplified process for rescue team members, as follows:

First, the recipient state may issue special passes for those registered in a list provided by a sending state authority (Arab Cooperation Agreement Regulating and Facilitating Relief Operations 1987: art 8). This means that visa and, in some cases, passports are not required in an emergency, similar to the treatment of military personnel under a status of forces agreement (NATO/ SOFA 1951: art 3). Second, only passport and/or identification cards may be accepted as sufficient proof for rescue workers (ASEAN Agreement on Disaster Management and Emergency Response 2005: art15, InterAmerican Convention to Facilitate Disaster Assistance 1996). This will need a guarantee by the sending state for personnel on a list submitted through diplomatic or consular channels. In case of emergency, such a list may be a handwritten non-typed letter, and handed by embassy staff-members. For port or airport clearance, too, a rescue team member list may be accepted as a guarantee for the members' identities and eligibilities. Such simplification should be followed by team-based collective operations by the rescue team, as well as the guarantee of departure immediately after the completion of their missions. What should be a proper handling if immigration authorities are totally devastated, leading to no functioning of immigration screening process? Absent of consent by the host state, such a case might require the United Nations Security Council resolution enabling foreign rescue workers to enter the affected state by eliminating sovereign barriers.

In exiting intergovernmental legal or non-legal frameworks and instruments, a typical textual formulation for relaxing immigration procedures is to 'facilitate' the entry and departure of rescue teams. Here, 'facilitate' is a catch-all term; thus, its details need more clarification in practice. This term is used, for instance, in the 1971 United Nations General Assembly Resolution 2816/ XXVI ('facilitate disaster relief') and the 1991 Resolution 46/182 ('facilitate access') (UNGA 1977:127, et UNGA 1991). The 1987 Arab Cooperation Agreement Regulating and Facilitating Relief Operations sets out 'pledge to coordinate [contracting parties'] efforts ...with the aim of speeding up and facilitating measures.' (Arab Cooperation Agreement Regulating and Facilitating Relief Operations 1987). In drafting texts, 'facilitate' generally implies the discretion by parties on specific measures to be taken, so there is no obligation to amend or modify domestic legal instruments (Marrakesh Agreement Establishing the World Trade Organisation 1994: art III). For more clarity, the formula, 'reduce or simplify administrative procedures', signifies specific and clearer duties on the side of contracting parties. The 2002 General Assembly Resolution 57/150 uses this formula ('simplify/ reduce to a minimum the administrative and customs formalities') (UNGA 2003).

In specialised areas, such as status of forces agreements or civilian aid instruments, there are cases that specific measures are prescribed, such as visa exemption or the issuance of special passes (NATO/SOFA 1951: art $3)$. There are instruments which prescribe further specific procedural requirements. The 1977 General Assembly Resolution A/32/61, Annex II, Measure to Expedite International Reliefs sets out special visas for aid personnel (UNGA 1991). The 2005 Association of Southeast Asia Nations (ASEAN) Agreement on Disaster Management and Emergency Response, requiring movement orders and passports or identification cards (ASEA N Agreement 2005: art 14, b). The European Union Regulation 539/1991/EC prescribes visa exemption, while allowing a member state to require written declaration on identities from a home state (European Union 1991: art 4(1)).

In the area of port/airport clearance, the 1965 Maritime Traffic Convention sets out rules to 'simplify documents' and 'limit regulatory measures' (Convention of Facilitation of International Maritime Traffic 1965). The 2005 International Civil Aviation Convention, Annex 9, includes rules on visa/documents waiver in an emergency (Convention on International Civil Aviation 2005: Annex 9, ch 3).

In sum, from the viewpoint of immigration simplification, preregistration for the entry of rescue workers will be cumbersome in an emergency. The list of workers may be guaranteed by the sending state or international organisations. Such a list can be submitted by an embassy or consular office. There are practical methods of expediting the entry by introducing a designated entry site, ideally in the form of one-roof or one-stop services (IFRC 2007b: ch 10). A temporary immigration arrangement may emulate the designation of deregulated areas or zones in regulatory policies (Kodama 2001).

The entry of rescue workers may cause an issue of vaccination, as to whether the workers show proper vaccination certificates or not, for instance. This issue is analogous with the risk assessment approach to quarantine, which was discussed in the previous part on rescue dog entry. There will be ways to simplify documentation and screening procedures, while maintaining the substantive requirements of vaccination. 


\section{Customs and quarantine procedures for emergency aid materials}

In an emergency caused by natural disasters, it is necessary to eliminate or reduce tariffs upon emergency aid materials, as well as to exempt or simplify procedural requirements for customs screening. In the application of quarantine regulations in customs procedures, prioritisation and simplification may also be required as prerequisite. One cannot imagine the imposition of tariffs or cumbersome customs procedures upon aid materials, which has a crucial stake in initial life-saving operations and subsequent recovery phases.

In some cases, well-established customs and quarantine regulations may cause impediments to the smooth operations of aid materials transfer into the affected state. In 2005, after the Sri Lanka earthquake, the local authorities maintained routine customs procedures upon foreign relief containers, which caused significant delays in distributing aid materials (Bannon and Fisher 2006). In the same year of 2005, in the Hurricane Katrina disaster, UK food aid materials were refused for admission due to Bovine Spongiform Encephalopathy (BSB) regulations by the US quarantine authorities (Connolly 2005). In also 2005, after the Guatemala earthquake, full documentation requirements for customs procedures were required by the local authorities on the spot for 60 days after the occurrence of the earthquake (IFRC 2007c: 27).

Issues at stake are composed of (1) substantive requirements for products and (2) procedural rules for screening and examination. The substantive issues have an analogy with the entry of rescue dogs and rescue personnel in terms of need and balance for relaxing or modifying rules in an emergency. In this regard, international non-legally binding guidelines for quality standards are already compiled under the 2011 Sphere Project, which was started in 1997 by the International Red Cross and Crescent (Sphere Association 2018). The 2018 Sphere Handbook contains standards for specific items, such as water, food, shelter, clothing, beddings, and households (Sphere Association 2018: 2). Amongst these items, equipment and facilities for basic living conditions should be more relevant in recovery phases. The initial rescue phase should concentrate upon basic human need materials, such as water, food, tents, blankets, and basic hygiene products, for which further quality standardisation will be useful.

Procedural issues require considering methods and measures to reduce administrative burdens in the process of admitting foreign aid materials. In practice, the elimination or reduction of tariffs as well as procedural rationalisation are generally well-coordinated in most states (Centre 2014: duty-free entry of materials). Intergovernmental frameworks are relatively well-developed, in general customs regulations as well as specific areas of materials (Kyoto Convention 1999; Istanbul Convention 1990). This derives from the following background conditions: First, customs operations are generally easy to specify and control, by using border or port/airport checkpoints and pinpointing certain materials designated for specific purposes (Kyoto Convention 1999: ch 3). Second, customs administrations are centralised and institutionalised with professional hierarchical command procedures in each border post (ch 6). Such welldeveloped institutionalisation may bring about strict ordinary customs procedures as well as systematic relaxation in emergency, depending upon policy directions managed by customs authorities to tackle natural disaster damage. In addition, third, customs procedures are subject to welldeveloped intergovernmental cooperation, led by the World Customs Organization (WCO) as an international authoritative body by professional experts (ch 9). The WCO has consecutively consulted and discussed for possible frameworks on adjusting and rationalising customs procedures in the case of an emergency (art 15 etc.).

Examples of procedural rationalising methods are provided in existing international frameworks. The 1977 United Nations General Assembly Resolution Annex provides, for instance, the acceptance of delay in documentation, the use of a single declaration for relevant materials, minimum customs examination, and customs post centralisation (UNGA 1977: 127). It also includes the need for opening customs posts in extra working hours in emergency (UNGA 1977: Annex F.5, 9, e). The 1974 WCO Convention on the Simplification and Harmonization of Customs Procedures (Kyoto Convention), as amended in 1999, sets out methods of simplifying customs requirements, such as document reduction, the allowance of delay in documentation, fast-track treatment, the elimination of fees, process acceleration, and flexibility in changing items (Kyoto Convention 1999: Annexe Generale). Its Annex J, Chapter Five, specifically treats relief consignments, providing tax-free treatment and the issuance of a note for smooth procedural requirements (Specific Annex J, ch 5). The WCO Kyoto Convention is basically aimed at trade promotion by eliminating tariffs and relevant procedures (Preamble). It needs more deliberate considerations upon devastating natural disaster occurrence, which urgently require a free and smooth passage of aid materials at initial stages.

The 1990 Istanbul Convention on Temporary Admission, Annex B9, also provides rules and guidelines for relief materials (Istanbul Convention 1990: Annex B.9). Methods are prescribed, like prior authorisation in an exporting state as well as the introduction of admission paper as simplified version of documentation (Annex A). The Istanbul Convention, too, basically aims for trade promotion, and it requires the re-export of items after temporary admission, which is generally not the case for 
emergency materials (preamble). Emergency aid materials are consumed and used in affected areas, especially at the initial rescue phase.

The 2011 WCO Resolution on relief consignments provides the need for expediting and facilitating procedures, specifically in terms of documentation (WCO 2011). In large-scale natural disaster emergency, customs and quarantine documentation require significant simplification and prioritised treatment. It is at least inappropriate to require document submission on arrival and bond requirements as guarantee for later satisfying documentation requirements. As in the case of immigration procedures, the list of items (product description and quantities) submitted by embassy or consular channels as the sending state's guarantee will be most appropriate, depending upon the characteristics of each material under regulatory treatments. Thus, it is meaningful to examine customs and regulatory treatment in specific products, in view of characteristics and regulatory needs, for instance whether the product at issue is well standardised or highly sophisticated or not, thus requiring careful treatment.

Some regional frameworks provide customs special procedures in the case of emergency: The European Union Council Regulation 2454/83 provides for products to be circulated within the Union the exemption of duties upon relief materials (European Union 1983). The 1987 Arab Cooperation Agreement Regulating and Facilitating Relief Operations provides in Article 7 comprehensive rules that no charges shall be imposed upon aid materials and that procedural priorities shall be offered for such items (Arab Agreement 1987: art 7 (3)).

Customs reduction and deregulation may be treated differently in specific areas of product items, given the difference of characteristics and regulatory policy needs. Customs requirements are linked with domestic regulatory rules in most cases, depending upon each product item (Kyoto Convention 1999: Specific Annexes). In this regard, intergovernmental frameworks vary in terms of comprehensiveness of scopes. In some areas, emergency disaster treatment concentrates upon mainly customs duty reduction and procedural simplification, as well as some provisions on procedural facilitation for immigration (Kyoto Convention 1999, as a typical case). This type of frameworks may be categorised as 'Type A'. There are other frameworks which set out more comprehensive rules including something closer to privileges and immunities for those who carry items, such as rules on liabilities in the case of damage and injury to a third party as well as criminal immunities in the case of criminal offences in the performance of operations (Tampere Convention 1998). This second comprehensive type of framework may be designated as 'Type B'. This categorisation will be used as a tool for analysis in the following examination on frameworks in specific areas. (Table 1 describes such two types of intergovernmental frameworks.)

In the area of pharmaceuticals, multilateral guidelines for permissible lists are relatively well developed, as in the 2015 World Health Organization (WHO) Essential Medicine Model List, including vaccines, Bacille Calmette-Guérin (BCG), and blood compounds, attributing the sending state for responsibilities with due diligence (WHO 2015). Thus, it touches upon civil liability issues, relieving the recipient state of responsibilities for misuse of medicines. The 1999 WHO Drug Donation Guideline prescribes the treatment of medicines in an emergency, with details about special care and the prevention of misuse (WHO 1999: IV). With these lists and guidelines, linked with the general treatment of emergency aid materials, such as the Kyoto Protocol of Customs Simplification, the pharmaceutical area has established a well-developed 'Type A' arrangement on emergency treatment (Kyoto Convention 1999).

In the area of telecommunication services and equipment, the 1998 Tampere Convention on emergency telecommunications established an advanced comprehensive framework for post-disaster operations (Tampere Convention 1998: preamble). The Convention reduces or removes regulatory barriers, with clearly specified methods, including duty-free and deregulatory measures for admitting telecommunication equipment, as well as its usage in a domestic sphere under simplified regulations (art 9). The Convention also provides privilege and immunities for telecommunication technical experts handling such equipment (art 5). Thus the Tampere Convention falls upon a 'Type B' intergovernmental framework for emergency responses. One debatable issue regarding the rules under the Convention is its cost allocation disbursed by the recipient state, which needs flexible allocation depending upon the recipient state's affordability and the need to avoid complication in financial settlement (art 7). Rescue operations should not cause extra burdens upon disaster-affected states.

\section{Transport to and within affected areas Driving licenses}

Transport vehicles are crucial in the initial phase of natural disaster reliefs for transporting rescue teams and materials within the recipient state, particularly from a trans-frontier border to affected areas in the recipient state as well as within affected areas for delivery and operations. Other than customs issues, there are two dimensions which need considerations: that is, first, the recognition of driving licenses and, second, vehicle registration in the affected state in terms of technical standards and environmental emission criteria required for a vehicle in motion on public roads in that state. 
Table 1. Two categories of sectoral or regional inter-governmental arrangements for facilating natural disaster rescue/relief operations

Type A

Provisions on basic facilitative measures, such as immigration facilitation, customs

reduction/elimination, favourable regulatory treatment, simplified screening procedures, etc.

\section{Examples:}

-International Convention on the Simplification and Harmonisation of Customs Procedures, as amended, signed in 1974, revised in 1999. Chapter 5 Relief Consignments.

-Convention on Temporary Admission, signed in Istanbul on 26 June 1990, Annex B.9 Annex concerning Goods imported for Humanitarian Purposes.

\section{Type B}

In addition to Type A provisions, provisions on civil liability waiver and criminal immunities, etc.

\section{Examples:}

-Tampere Convention on the Provision of Telecommunication Resources for Disaster Mitigation and Relief Operation, in 1998, especially Article 5 Privileges, Immunities, and Facilities.

On the issue of driving licenses, the policy need is to allow drivers of an assisting state to drive freely within the recipient state with his or her license granted by the government of the assisting state. That driver should be well qualified for driving a vehicle in an emergency, and one can eliminate the burden of summoning a limited number of competent drivers by the host state in emergency situations.

The 1949 Road Traffic Convention (Geneva Convention) provides in Article 24 that a driver from a contracting party is allowed to drive in the territory of another contracting party with a license in accordance with model deriving license forms prescribed in the Convention, as long as the vehicle is for transporting personal baggage, not for hiring a car or getting rewards (Convention on Road Traffic 1949: art 24, 1). If this rule is applied to emergency disaster relief cases, initial relief operations will become significantly smooth and efficient, given the quasi universal acceptance of the Geneva
Convention. ${ }^{3}$ Under the Convention, drivers may use international driving licenses, but drivers for aid transportation are not always ready to obtain international driving licenses, in the country of professional rescue workers. The 1954 Customs Convention on the Temporary Importation of Private Road Vehicle, as a related treaty for the 1949 Geneva Convention, defines the 'private use' of vehicles as those excluding transport for remuneration, reward, and industrial or commercial transport (Customs Convention on the Temporary Importation of Private Road Vehicles 1954: art 1). Thus, non-industrial and non-commercial transport are covered by the 1949 Custom Convention as well as the 1949 Road Traffic Convention. So, there is room for including disaster relief transport within the scope of application of the Geneva Convention. Given the lack of

\footnotetext{
${ }^{3}$ signatories:19, parties: 97.
} 
multilateral intergovernmental arrangement explicitly covering disaster relief transport, such an interpretative approach will be worth considering.

In the application of the 1949 Geneva Convention, some contracting parties require under their domestic laws and regulations the attachment of local language translation for the home country's driving license (IFRC 2007b: ch11). This requirement should be exempted in the case of natural disaster emergency. The assisting state's official guarantee for legitimate driving licenses through diplomatic or consular channels should be considered to be sufficient for recognition.

Driving licenses are examples of professional qualification recognition in emergency situations. It relates national safety standards and difficulties in driving in a state with different traffic rules and road conditions. It is a policy choice whether professional drivers duly licensed in the sending state should be allowed to drive in the recipient state or not. This is an area where a prearranged intergovernmental framework is of significant value. This is particularly true, given the fact that the 1968 Vienna Convention on Road Traffic, covering all forms of driving for the mutual recognition of driving in contracting parties' territories, is not universally ratified (Convention on Road Traffic 1968).

\section{Vehicle registration}

Another issue in admitting transport vehicles for carrying rescue teams and aid materials lies in a vehicle itself. Each state requires the registration of vehicles by screening its fulfillment of technical standards and emissions criteria (art 18). Then vehicles with legitimate certificates are allowed to be driven in that state. This issue will also be solved, as in the case of driving licenses that the 1949 Geneva Convention on Road Traffic is applied to disaster relief vehicles as 'non-commercial and non-industrial use of vehicles' (art 5). In addition, the 1954 Customs Convention on the Temporary Importation of Private Road Vehicles provides the exemption of duties, taxes, and any regulatory restrictions for temporary visit for private use (Customs Convention 1954, art 1). It will be ideal that these conventions are applied to the use of vehicles for emergency disaster relief operations.

The 1956 Customs Convention on the Temporary Importation of Commercial Road Vehicles provides a broad exemption for procedures in admitting vehicles for commercial use (Customs Convention 1954). There are small rooms for applying this convention to disaster relief emergency situations, if by any chance, 'commercial use' is interpreted broadly. The Convention formulates temporary importation papers which is cumbersome in an emergency, though (ch III).

\section{Tolls and charges}

One more issue for transport vehicles used for transporting rescue teams and aid materials in the recipient state is the reduction or exemption of traffic tolls and charges when using motorways, for instance, toward affected areas. Aid workers' vehicles may be allowed to use fast-track lanes in road tolls. There is a widely prevalent practice that at least the national treatment principle is applied to such cases, that is to say, foreign aid vehicles are relieved of traffic tolls and charges to the same extent as treatment for national rescue team vehicles in the recipient states (Agreement between the Government of Australia and the Government of French Republic regarding Defence Cooperation and Status of Forces 2009: sec 15 (3)). The designation of such vehicles may be made through diplomatic or consular channels in an emergency.

One example is the 1987 Arab Cooperation Agreement Regulating and Facilitating Relief Operations, which provides in Article 7(5) that traffic charges are eliminated, provided that national services for disaster reliefs are treated free of charge (Arab Agreement 1987: art 7 (5)).

\section{Medical treatment-qualification issues}

Medical teams with professional medical doctors as well as nurses and technicians, if necessary, on radiography and rehabilitation, for instance, are significantly important for saving lives in the aftermath of natural disasters (IFRC 2007b: ch 10.2). This is all the more urgently needed in the phase immediately after the occurrence of an earthquake and any other large-scale disasters. Medical teams shall be urgently admitted and be allowed to engage in medical care activities in affected areas. Problems exist in both medical teams' capacity and their qualifications by which medical doctors authorised in the sending state are duly allowed to conduct medical activities in the host state.

First, medical doctors should own capabilities required for rescue and recovery operations, for instance, emergency life-saving activities and immediate surgical operations, if necessary. Routine clinical care may also become insufficient in terms of resources and personnel, given the need to prioritise rescue and life-saving operations, especially at an early stage of rescue phases. Local medical doctors are, in most cases, engaged in immediate life-saving treatment, thus foreign medical teams, arriving at affected spots with a time lag, may face the need to engage in clinical cares, including gynecology, geriatrics, and pediatrics. Foreign medical doctors may pay attention to local health and medical conditions. Medicine prescription and dosing should correspond to local people's physical characteristics and overall surrounding conditions (IFRC 2007a). In order to cope with 
these elements, prearranged trainings and analysis will be practically important for forming reserve medical teams in potential donor states.

Second, more severely, medical professions normally require strict control in a state, with their nationally specific requirements and regulatory policy for controlling medical professions' numbers. In addition, national medical qualifications require the use of a national language, since interviewing and assisting by communicating through a local language is a crucial part of medical treatment. Regulatory control will become more comprehensive in the case of establishing a hospital. In emergency operations, the establishment of field hospitals and the dispatch of hospital ships are also expected to contribute to general rescue and recovery operations (WHO and IFRC 2017: Box 2). In most countries, regulatory requirements for establishing a hospital in peacetime are detailed and voluminous. Professional qualifications are also required for technical experts like radiographers and rehabilitation trainers, for instance. This will further add regulatory issues in admitting medical teams with medical facilities and equipment. There is an issue of doctors' liabilities caused by medical misconduct with negligence, which may cause compensation under the host state's national laws, then also requiring the arrangement of insurance. Such issues are taken care of on an ad hoc basis in an emergency. Difficulties in recognising medical professional qualifications and other regulatory requirements lie in the lack of mutuality or reciprocity in recognition, unlike cases for regulatory relaxations in other areas like aid materials. There is no time in an emergency to assess and compare details of medical qualifications between the sending and the host states.

In order to cope with capacity and quality standards for medical doctors, there are several multilateral attempts to formulate quality control benchmarks for doctors. The Sphere Report simulates basic requirements for emergency medical activities (Sphere Association 2018, Minimum Standards in Health Action). The report states that inappropriate or inadequate surgery may do more harm than doing nothing' then requiring proper level of surgical capacities of medical doctors in rescue teams (Sphere Association 2018: 5). The 2017 WHO Studies on Emergency Medical Teams presents items and benchmarks for the quality control of medical teams (WHO and IFRC 2017: Types of emergency medical teams (EMT)). The studies categorise the level of functions of foreign medical teams by (1) 'outpatient emergency case', roughly corresponding to 'primary care', (2) 'inpatient surgical care', and (3) 'inpatient referral care' (WHO and IFRC 2017: EMT Type 1, EMT Type 2, EMT Type 3). The 2013 WHO Classification and Medical Standards for Foreign Medical Teams propose global qualifications and registrations, in order to facilitate national states' recognition of foreign medical professions (WHO 2013). These instruments offer bases for rosters or reserves to be included in emergency rescue teams. The real issue exists in the difficulties in recognising foreign medical professional qualifications under the host state's relevant law and regulations. Discussions on possible global recognition of medical professions in an emergency have not been actively engaged, due to the difficulties in treating highly qualified professions which are related to life and death.

Medical qualifications can be treated flexibly in emergency situations, while limiting the scope of medical activities to be conducted by foreign medical teams. This was the case in the 2011 East Japan Earthquake, when the Government of Japan issued a Ministerial notice to the effect that foreign medical doctors should be exempted from medical law requirements, then as legitimate activities not constituting a criminal offence (WHO and IFRC 2017: Box 4). This notice was applied to primary care phases, including initial assessment, resurrection, and initial rehabilitation care, though not clearly defined. The Government of Japan also limited the countries of origin for medical teams to be accepted to four countries, namely the Philippines, Thailand, Jordan, and Israel (Box 3). Criteria for selecting these countries, not geographically immediate neighbors, were, for instance, experience owned by doctors in the team as students or visiting scholars in the host state's medical institutes; similarities in local climatic conditions and patients' physical characteristics; and the existence of sister relations between hospitals in affected areas and those in the sending state. Therefore, the 2011 medical profession notice for regulatory relaxation by the Government of Japan was applied in a narrow domain, thus not suitable for comprehensive framework of medical profession recognition in an emergency.

Realistically, the limit of scopes and patients may facilitate the acceptance of foreign medical doctors in an emergency to a certain extent. As was the case in the 2011 Japanese governmental notice, the limit to primary care may enable the scope of activities to be conducted by foreign doctors. In the areas of surgical treatment and medicine prescription, regulatory impediments are far higher, requiring intergovernmental prearrangements. The scope of permissible medical treatment may vary in patients dealt with by foreign teams. First, the treatment of members of rescue teams, especially military personnel, may be engaged by the team's doctors, including surgical operations and medicine prescription. This may be included in prearrangements, including defence cooperation agreements, which may be applied mutatis mutandis to civilian rescue teams. Second, foreign medical teams may be allocated to treat their own nationals staying or travelling in the host state. This may be justified by the reasoning of personality (nationality) jurisdiction, with 
Table 2. Recognition of medical profession qualification with personnel scopes and treatment

\begin{tabular}{|l||l|l|l|}
\hline \multicolumn{1}{|c||}{ Treatment } & Primary Care & $\begin{array}{l}\text { Surgical Treatment } \\
\text { including amputation, } \\
\text { reproductive surgery, and } \\
\text { anaesthesia. }\end{array}$ & $\begin{array}{l}\text { Medicine Prescription } \\
\text { and General Clinical } \\
\text { Care }\end{array}$ \\
\hline \hline Scope of Patients & Defence Cooperation \\
Especially Military Personnel & Arrangements & $\begin{array}{l}\text { Defence Cooperation } \\
\text { Arrangements }\end{array}$ & $\begin{array}{l}\text { Defence Cooperation } \\
\text { Arrangements }\end{array}$ \\
\hline Assisting State Nationals & Non-binding Guidelines & $\begin{array}{l}\text { Personality Jurisdiction, } \\
\text { with the host State's } \\
\text { consent }\end{array}$ & $\begin{array}{l}\text { Personality Jurisdiction, } \\
\text { with the host State's } \\
\text { consent }\end{array}$ \\
\hline Host State Nationals & Non-binding Guidelines & Ad-hoc Arrangements & Ad-hoc Arrangements \\
\hline
\end{tabular}

the consent by the host state (Brownlie 1990: 303). Third, the treatment of the host state's nationals will require intergovernmental arrangements. Such categorisation may be considered in formulating an intergovernmental arrangement for recognising medical doctors' treatment in an emergency, with the specified scope of treatment and benefactors. (Table 2 summarises such categorisation.)

\section{Civil jurisdiction}

An issue which has been sporadically treated under intergovernmental arrangements is the application of civil jurisdiction under the recipient state's domestic laws and regulations to foreign rescue and relief workers for incidents which occurred in their relief operations (Tampere Convention 1998: art 5). Typically, aid workers may cause a traffic accident when transporting aid materials to affected areas, bringing about civil damage claims from local third parties. A foreign medical team may commit misconduct in their life-saving operations, causing tort damage claims by patients.

This is an issue of jurisdictional coordination, whether foreign rescue workers are treated in a differentiated manner under domestic civil laws and procedures in the recipient state, taking into account their special mission for rescuing and saving human lives in a post-disaster phase. Therefore, this issue relates the extent to which the receiving state's sovereign jurisdiction is extended, while whether the receiving state's consent for accepting foreign rescue workers implies the willingness to give advantages to such workers or not. At the same time, it is an issue of risk allocation between the sending and the receiving states, as to which state owes costs of vicarious incidents accompanying rescue activities. Thus, it can be considered from the viewpoint of economic and social conditions in the receiving state. It can also be a policy issue as to how to ensure efficiency and motivation for foreign rescue workers. Rescue workers are engaged in dangerous operations in disaster-affected areas which may involve their life and safety. In order to restrain their hesitations and promote their morale, exemptions from litigation procedures may be productive, as in the case of military personnel engaged in defence operations in a foreign country.

Rescue workers are temporary visitors with the missions of rescue and relief operations in a foreign country. This temporary character may favor the special treatment of workers, which may justify exemption or possible immunities from local laws and procedures. On the other hand, temporariness may lower the need for special treatment, unlike diplomatic personnel, or members of forces stationed in permanent bases, who are, in most cases, protected under a status of forces agreement (Jennings and Watts 1992: 1154). This brings about a policy issue as to how military or diplomatic privileges and immunities may apply mutatis mutandis to civilian aid workers (Bartolini 2015). It may be relatively easier to apply to governmental rescue team members granted and registered by the sending state. On this issue, intergovernmental rules and practice have not established universal norms at the current stage. 
Regional arrangements demonstrated various principles and treatment, based upon different socioeconomic conditions in relevant states. The European Union internal regulations have limited interest in civil claims in the case of disaster relief operations by foreign aid workers, presumably reflecting their member states' well-developed domestic laws and judicial systems (IFRC 2010: VII). The 1987 Arab Cooperation Agreement regulation and facilitating Relief Operations follows the suit, with no mentioning of civil or criminal jurisdictions (Arab Agreement 1987). On the other hand, the 1996 Inter-American national Convention to Facilitate Disaster Assistance stipulates rules favorable for the assisting state to a similar extent as diplomatic and military privileges and immunities (Inter-American Convention 1996: art XII). It stipulates that 'assistance personnel whose names have been duly communicated to the assisted state and who have been accepted by the assisted state... shall not be subject to... civil or administrative jurisdiction of the assisted state for acts connected with the provision of assistance,... [except for cases with] willful misconduct or gross negligence' (Art XII, b). The convention also provides that 'the assisted state waives any claim for loss or damage... as a result of provision of assistance', and that 'the assisted state shall substitute for... the assistance personnel with respect to claims for loss or damage...'(Art XII, a). The formulation of 'acts connected with the provision of assistance' may imply broad exemption, not limited to exact rescue and relief actions. The 2004 Association of Southeast Asian Nations (ASEAN) Agreement on Disaster Management and Emergency Response stipulates duties by contracting parties to consult and coordinate claims issues 'arising out of performance of official duties', except for cases with 'gross negligence and contractual claims' (ASEAN Agreement 2005: art 12).

The most developed sector-based arrangement, as a 'Type B' framework, stipulates as follows: The 1998 Tampere Convention on the Provision of Telecommunication Resources for Disaster Mitigation and Relief Operation sets out in Article 5 that privileges and immunities shall be afforded by the receiving state to telecommunication assistance personnel generally, especially immunity from legal process in civil and administrative jurisdiction, in respect of acts or omissions specifically and directly related to the provision of telecommunication assistance' (Tampere Convention 1998: art 5). This 'specifically and directly related to assistance' formula is distinctively narrow as the scope of immunities, reflecting the immunity granted to broad-ranged assistance workers. This is an exceptionally welldeveloped case for immunities for civilian aid workers in a specific sector.
Military arrangements provide broad immunities and special treatment for military personnel, considering their tasks and the practice of military immunities under general international law, as will be examined later in details in the subsequent section of this article (Jennings and Watts 1992: 1154; Bartolini 2015). Whether such immunities may be applied to civil aid workers, especially governmental rescue and relief team members, is a matter of policy choice. Military arrangements, typically status of forces agreements and visiting forces agreements, provide the waiver of civil claims vis-à-vis host states' property and military personnel; the receiving state's handling of liability vis-à-vis third parties including substitution and cost bearing in some cases in the receiving state; and the sending state's handling of ex grata payment for liability not in the performance of official duties. In any case, military personnel are immune from the exercise of enforcement jurisdiction, reflecting the development of military immunities under general international law (Tampere Convention 1998: art 5). The possible application of these rules to governmental or civilian rescue and relief workers is examined as follows:

First, the possibility of applying immunities from liability vis-à-vis a receiving state's property or personnel may be considered in favor of rescue and relief workers. The 1951 North Atlantic Treaty Organisation (NATO) Status of Forces Agreement stipulates that 'all claims against any other contacting party for damage to its property and armed service members' shall be waivered (NATO/ SOFA 1951: art 8, 1. i). Waivered damage to property was caused 'in the execution of... duties in connection with the operation of the North Atlantic Treaty', and damage to military personnel was caused while members are engaged in the performance of official duties. ${ }^{4}$ The formula, 'in connection with the operation', literally includes actions not directly relevant for duties. The 2006 France/Australia Defense Cooperation Agreement stipulates in the same cases that damage should be in the course of official duties'. ${ }^{5}$ This seems to be more limited to directly relevant actions of duties. Rescue and relief workers have little ground to be protected in their actions outside of rescue operations, unlike military personnel based in a base in the host state. Unlike permanent based military personnel, traffic accident in the course of commuting to a main site in affected areas needs not to be exempted from liability (Lazareff 1971: sec 5, para 2). Traffic accidents in the course of dining

\footnotetext{
${ }^{4}$ In the French version, 'dans l'exercise de ses fonctions dans le cadre du Traité de l'Atlantique Nord', so 'in the connection with the operation of the North Atlantic Treaty' may connote broadly actions and contents within the function of the Treaty.

${ }^{5}$ France/Australia Agreement 2009, The French version stipulates: 'dans le cadre de l'exercise de ses fonctions officielles'.
} 
out to a restaurant in a neighboring town in a break time have also little ground for granting immunities. It will be also appropriate to limit waived liability to cases without willful conduct and gross negligence, as is provided in the NATO-Germany Supplementary Agreement to Supplement the NATO Status of Forces Agreement with respect to Foreign Forces stationed in the Federal Republic of Germany (Revised Supplementary Agreement 1993).

Second, military arrangements provide the handling by the receiving state for liabilities claimed by third parties, caused by acts or omissions 'in the performance of official duties', in the case of the NATO Status of Forces Agreement and the France/Australia Defense Cooperation Agreement, for instance. ${ }^{6}$ The substitution by the receiving state for coordination with claimants as well as the handling of judicial procedures may be reasonable, given the expertise owned by the receiving state about its relevant domestic laws and regulations. It may also contribute to efficient settlement in favor of third-party claimants. Status of forces agreements also generally provides the payment of liability damage or part of it as host nation support. For rescue and relief workers, this matter may well be in line with cost sharing policy for assistance operations, on which international instruments have a variety of practice. It can be reasonably considered to relieve the receiving states of extra costs for aid operations. ${ }^{7}$

Third, military arrangements also provide the settlement of third-party damage not done in the performance of official duties, handled by the host state. This part has less ground to apply to aid workers, who shall be unless otherwise under the jurisdiction of the receiving state's domestic laws and regulations.

\section{Criminal jurisdiction}

The application of the receiving state's criminal laws and procedures to foreign rescue and relief aid workers in their operations within that state generally duplicate with argument concerning the application of civil jurisdiction. Typical cases relating foreign aid workers may be traffic accidents in the course of transporting personnel and aid materials, as well as medical misconducts committed by foreign medical team doctors. Unlike military personnel, to which traditional military immunities may apply under general international law, a room for exempting aid workers from domestic criminal jurisdiction is further limited (Jennings and Watts 1992: sec 556). Status of forces agreements and visiting forces agreements generally stipulate the exercise of the sending state's criminal jurisdiction to military members,

\footnotetext{
${ }^{6}$ France/Australia Agreement 2009, The French version stipulates: 'dans l'exercise de leurs fonctions offcielles'.

${ }^{7}$ Contre, Tampere Convention 1998: art 7.
}

which excludes the application of the receiving state's criminal laws and regulations. This extraneous treatment departing from the sovereign principle may face difficulties in the case of civilian personnel. On the other hand, protection and special treatment for foreign suspects engaged in rescue operations in emergency conditions may well be justified as extension of consular assistance offered by diplomatic and consular outlets for their own nationals in the receiving states (Jennings and Watts 1992: 1139).

There are a limited number of intergovernmental instruments which cover immunity from criminal jurisdiction for rescue workers. The 1996 Inter-American Convention to Facilitate Disaster Assistance sets out that assistance personnel properly registered by the sending state 'shall not be subject to the criminal...jurisdiction of the assisted state for acts connected with the provision of assistance' (Inter-American Convention 1996: art XII). This formula and broad scope for exemption is quite unique as a regional cooperation agreement. The 1998 Tampere Convention on the Provision of Telecommunication Resources for Disaster Mitigation and Relief Operation provides that 'the requesting state party shall... afford to persons providing telecommunication assistance immunity from arrest, detention and legal process, including...criminal jurisdiction of the requesting state party, in respect of acts or omissions specifically and directly related to the provision of telecommunication assistance' (Tampere Convention 1998: art 5). This is a formula with narrowly limited scope of actions, but subject to comprehensive immunity from local criminal procedures.

The 1951 NATO Status of Forces Agreement stipulates the application of the sending state's criminal jurisdiction to military force members 'in relation to' 'offences arising out of any act or omission done in the performance of official duty' (NATO/SOFA 1951: art 7). The 2006 France/Australia Defense Cooperation Agreement, on the other hand, sets out such application to offences 'arising out of any act or omission done in the course of official duty' (France/Australia Agreement 2009: sec 3(3) (a) (iv)). These are rules for military personnel reflecting the traditional practice of military immunity under general international law. The temporary nature of aid workers' stay in the receiving state further reduce the need for jurisdictional exemptions, unlike military personnel stationed in a permanent base in a host state (Jennings and Watts 1992: sec 556).

The NATO Status of Forces Agreement also stipulates assistance for suspects and the accused, similarly to consular assistance by foreign embassy or consular offices for their nationals seized by the host state's criminal procedures (NATO/SOFA 1951: art 7, 9). The prosecuted shall be entitled to notification, legal representation, 
competent interpreter, and communication with a consular representative from the sending state (b, e, f, g). Such a streamlined menu for assistance may well be emulated for foreign rescue and relief aid workers for their alleged offences in the course of assistance activities. It is submitted that this is a matter conducive to intergovernmental frameworks, ideally multilateral rule-makings for universal standardisation.

\section{Conclusions}

The earthquake which hit the east coast of Japan on 11 March 2011 revealed the fact that a highly regulated country like Japan suffered from regulatory and procedural impediments in receiving foreign rescue and relief units as well as emergency aid materials. Japan is a country with well-prepared natural disaster response mechanisms, including domestic rescue and relief procedures and resources. Japan is also a county with complex and sophisticated regulatory regimes in all dimensions in its economy and society. This caused difficulties in smoothly receiving foreign rescue and relief operations. Specific challenges and prescriptions are as follows:

In receiving foreign rescue and relief operations, especially aid personnel and units, self-sufficiency for their basic living conditions as well as operational needs, such as water, food, fuel, and shelter, will become an issue. In a receiving state which has established sophisticated networks of regulatory frameworks and institutions, for the purpose of protecting public health, safety, and security, there may be vicarious impeding effects upon smooth admission of foreign assistance in an emergency. In post-natural disaster assistance operations, there are issues related to standards and specifications of relevel tools and equipment, such as pallets and forklifts for transporting aid materials. In such cases, the flexible application of compulsory standards under domestic laws and regulations may well be considered.

In actual rescue and relief operations, regulatory regimes in the recipient state may create impediments upon smooth implementation. Examples are as follows:

The role of rescue dogs is crucial, particularly in the initial phase of rescue operations. The treatment of rescue dogs should be based upon epidemic risk assessment approach, by examining, for instance, past disease records in the host state, geographical figures and spaces, medical and hygienic conditions, and the capacity of the recipient state to treat possible epidemic damage. One may consider procedural rationalisation, such as delayed submission of certificates and possible first track screening for rescue dogs.

The entry of rescue teams, including rescue workers and medical experts, is also crucial for the initial lifesaving operations. In an emergency, the list of workers may be guaranteed by the sending state or by international organisations, which may be submitted by embassies or consular offices as well as international organisation branches.

In an emergency, it is necessary to reduce customs tariffs upon emergency materials, as well as to exempt or simplify procedural requirements for customs screenings. Customs reduction and deregulation may be treated differently in specific areas of product items, given the differences of characteristics and regulatory policy needs.

Transport vehicles are crucial in the initial phase of relief operations. The issue of recognising foreign driving licenses in an emergency can be solved by applying the 1949 Road Traffic Convention, through interpreting its scope in a flexible manner to cover emergency disasterrelated cases.

Medical teams with professional doctors and nurses, as well as technicians are significantly important in the phase immediately after the occurrence of large-scale natural disasters. Medical qualifications can be treated flexibly in an emergency by limiting the scope of medical activities to be conducted by foreign medical teams, like limiting to primary care.

The application of civil jurisdiction under the recipient state's domestic laws and regulations to foreign rescue and relief workers for incidents which have occurred in their relief operations may become an issue. The temporary nature of rescue workers' stay in the recipient state may justify exemption or possible immunities form local laws and procedures. Temporariness may also serve for argument that special exempting treatment will not be appropriate, unlike forces stationed on a permanent basis. On this matter, intergovernmental rules and practice have not established universal norms at the current stage. It may be worth considering the application of military immunities and relevant arrangements under general international law to governmental or civilian rescue and relief workers, for the sake of efficient settlement in favor of third parties.

The application of the receiving state's criminal laws and procedures to foreign rescue and relief aid workers in their operations within that state may also become an issue. Unlike military personnel, a room for exempting aid workers from domestic criminal jurisdiction is further limited. On the other hand, protection and special treatment for foreign suspects engaged in rescue operations in an emergency may well be justified as extension of consular assistance offered by the diplomatic and consular outlets of their own nations in the receiving state.

\section{Acknowledgements}

The author extends appreciation to insights and advice from Ms Gabrielle Emery, Coordinator for Asia Pacific Disaster Law Program, International Federation of Red Cross and Red Crescent Societies, Asia Pacific Regional Office, as well as Mr Steven Hill, Legal Adviser and Director, North Atlantic Treaty Organization. 


\section{Author's contributions}

The author(s) read and approved the final manuscript.

\section{Funding}

Not applicable.

\section{Availability of data and materials}

Not applicable.

\section{Competing interests}

Not applicable.

Received: 1 September 2020 Accepted: 30 November 2020

Published online: 02 January 2021

\section{References}

Agreement between the Government of Australia and the Government of French Republic regarding Defence Cooperation and Status of Forces (2009) ATNIF 29

Agreement between the Parties to the North Atlantic Treaty Regarding the Status of their Forces (NATO/SOFA) (1951) art 3, NATO basic documents, selected texts (NATO 2016) 56

Agreement on the Application of Sanitary and Phytosanitary Measures (1994) The results of the Uruguay round of multilateral trade negotiations, the legal texts. GATT Secretariat, Geneva, p 69

Arab Cooperation Agreement Regulating and Facilitating Relief Operations (1987) Arab League Decision No 39 https://www.ifrc.org/docs/idr//N644EN. pdf. Accessed 22 Aug 2018

Association of Southeast Asian Nations (ASEAN), Agreement on Disaster Management and Emergency Response (2005) http://agreement.asean.org/ media/download/20190702042042.pdf\#search=\%27ASEAN+Agreement+ disaster+management+emergency+response\%27. Accessed 23 Aug 2018.

Bannon, Victoria and Fisher, David (2006) Legal lessons in disaster relief from the tsunami: the Pakistan earthquake and Hurricane Katrina, Insights 10, issue 6.

Bartolini G (2015) Attribution of conduct and liability issues arising from international relief missions; theoretical and pragmatic approaches to guaranteeing accountability. Vanderbilt J Transnational Law 48:1029

Brownlie I (1990) Principles of public international law, 4th edn

Connolly C (2005) Katrina food aid blocked by US rules In: Washington Post (in press)

Convention of Facilitation of International Maritime Traffic (1965) UNTS 591:265

Convention on International Civil Aviation (2004) Annex 12, search and rescue, 8th edn. International Civil Aviation Organisation. https://www.pilot18.com/ wp-content/uploads/2017/10/Pilot18.com-ICAO-Annex-12-Search-and-Rescue. pdf. Accessed 15 Oct 2018.

Convention on International Civil Aviation (2005) 20th edn. UNTS 15: 295

Convention on Road Traffic (1949) UNTS 125:3

Convention on Road Traffic (1968) UNTS 1042: 17

Convention on Temporary Admission (Istanbul Convention) (1990) UNTS 817:313

Customs Convention on the Temporary Importation of Private Road Vehicles (1954) UNTS 282:249

Day MJ et al (2016) Guidelines for the vaccination of dogs and cats, compiled by the Vaccination Guidelines Group and the World Small Animal Veterinary Association. J Small Anim Pract 57

EU (1991) Council regulation 539/1991/EC, art 4(1)

EU (2003) Regulation (EC) No 998/2003/EC of the European Parliament and of the Council of 26 May 2003, OJ L 146, 13.6.2003, 1

European Union (EU) (1983) Council regulation 918/83/EEC

International Federation of Red Cross and Red Crescent IFRC (2007a) Guidelines for the domestic facilitation and regulation of international disaster relief and initial recovery assistance, IFRC Geneva.

IFRC (2007b) Law and legal issues in international disaster response: a desk study. IFRC, Geneva

IFRC (2007c) Legal issues from the international response to tropical storm Stan in Guatemala. IFRC, Geneva

IFRC (2010) Analysis of law in the European Union pertaining to cross-border disaster relief. IFRC, Geneva

IFRC (2013) Model act for the facilitation and regulation (with commentary). IFRC, Geneva

Inter-American Convention to Facilitate Disaster Assistance (1996) UNTS 438: 245
International Alert (2015) Compounding risk: disasters, fragility and conflict, policy brief, London

International Convention on the Simplification and Harmonisation of Customs Procedures (Kyoto Convention) (1999), As amended, Customs Cooperation Council (CCC), later World Customs Organization (WCO), entered into force in 1974, revised in 1999. https://eur-lex.europa.eu/legal-content/EN/TXT/?uri= LEGISSUM\%3Al06025. Accessed 8 Aug 2017.

International Development Centre of Japan ('Centre') (2014) Comprehensive review of assistance from overseas for the Great East Japan Earthquake. International Development Centre of Japan ('Centre'), Tokyo

International Law Commission (ILC) (2016) Draft articles on the protection of persons in the event of disasters, in report of the International Law Commission, The Work of its Sixty-Eighty Session. International Law Commission (ILC), Geneva

Japanese Fire and Disaster Management Agency (2013) Compiled records on the East Japan Great Earthquake, Tokyo (Japanese language. Trans: the author).

Jennings R, Watts A (1992) Oppenheim's international law, 9th edn. Longman, London

Joint Editorial Committee for the Report on the Great East Japan Earthquake Disaster (2014) Report on the Great East Japan Earthquake, Tokyo (Japanese language. Trans: the author)

Kodama Y (2001) Asia economic integration and the GATT-WTO regime. Kluwer, The Hague

Lazareff S (1971) Status of military forces under current international law. Sijthoff, The Hague

Marrakesh Agreement Establishing the World Trade Organisation (1994) Art III in the results on the Uruguay Round 7. Geneva

Mitchell T (2012) Options for including disaster resilience in post-2015 development goals. Background Note, London

Office for the Coordination of Humanitarian Affairs (OCHA) (2012) Field coordination support section, preparedness-response. International Search and Rescue Advisory Group, Guidelines and Methodology, Geneva

Revised Supplementary Agreement (RSA) To amend the agreement of 3 August 1959 between parties to the North Atlantic Treaty regarding the status of their forces with respect to foreign forces stationed in the Federal Republic of Germany (1993). https://www.state.gov/nato-sofa-germany-1993amendment. Accessed 15 Nov 2017.

Sivakumaran S (2015) Arbitrary Withholding of consent to humanitarian assistance in situation of disaster. International \& Comparative Law Quarterly 64:501

Sphere Association (2018) The sphere handbook, humanitarian charter and minimum standards in humanitarian response. Sphere Association, Geneva

Tampere Convention on the Provision of Telecommunication Resources for Disaster Mitigation and Relief Operation (1998) UNTS 2296:5

UNGA (1991) Resolution A/RES/46/182. UNGA, New York

UNGA (2003) Resolution A/RES/57/150. UNGA, New York

UNGA (2015) Resolution A/RES/69/283, Sendai framework for disaster risk reduction 2015-2030. UNGA, New York

UNGA (2016) Resolution 57/150. UNGA, New York

United Nations Economic and Social Council (ECOSOC) Integration Segment (2014) United Nations International strategy for disaster reduction. New York

United Nations General Assembly (UNGA) (1977) Resolution A/32/61. UNGA, New York

United Nations Office for Disaster Risk Reduction (2015) Disaster risk reduction and resilience in the 2030 agenda for sustainable development. United Nations Office for Disaster Risk Reduction, New York

WHO (2013) Classification and minimum standards for foreign medical teams in sudden onset disasters, health cluster. WHO, Geneva

WHO (2015) 19th WHO model list of essential medicines. WHO, Geneva

WHO, IFRC (2017) The regulation and management of international emergency medical team. WHO, Geneva

World Customs Organization (WCO) (2011) Resolution on relief consignments. WCO, Brussels

World Health Organization (WHO) (1999) Guidelines for drug donations. WHO, Geneva

World Organisation for Animal Health (2016) Terrestrial animal health code

\section{Publisher's Note}

Springer Nature remains neutral with regard to jurisdictional claims in published maps and institutional affiliations. 